\title{
Relationships between biochemical attributes (non-structural carbohydrates and phenolics) and natural durability against fungi in dry teak wood (Tectona grandis L. f.)
}

\author{
Florence Bobelé Niamké • Nadine Amusant • Jean-Paul Charpentier • Gilles Chaix • \\ Yves Baissac • Nabila Boutahar • Augustin Amissa Adima • Séraphin Kati-Coulibaly • \\ Christian Jay-Allemand
}

Received: 19 April 2010 / Accepted: 16 June 2010/Published online: 10 March 2011

(C) INRA and Springer Science+Business Media B.V. 2011

\begin{abstract}
- Introduction Non-structural carbohydrates and phenolic compounds are implicated in the natural durability of wood. In order to find the chemical traits of natural durability in teak wood, the radial distribution of phenolics compounds and non-structural carbohydrates were studied in trees ranked by contrasting natural durability class against Antrodia sp.

- Methods Non-structural carbohydrates were analyzed by spectrophotometry after enzymatic assays and phenolics compounds using HPLC.

- Results High concentrations of starch, sucrose, glucose, and fructose were found in the sapwood, whereas only trace amounts were found in the heartwood. In the sapwood, low concentrations of $\mathrm{H} 1$ (a hydroxycinnamic acid derivative) were specifically detected. Tectoquinone was also detected in
\end{abstract}

Handling Editor: Barry Gardiner

F. B. Niamké $\cdot$ N. Amusant $\cdot$ N. Boutahar

Unité de Recherche Préservation des Bois Tropicaux,

CIRAD/FORET 73,

rue Jean-François Breton TA 10/16,

34398 Montpellier Cedex 5, France

J.-P. Charpentier

INRA Orléans, Unité de Recherche Amélioration,

Génétique et Physiologie Forestières (AGPF), GENOBOIS,

2163 avenue de la Pomme de Pin CS 40001 Ardon,

45075 Orléans Cedex 2, France

F. B. Niamké • G. Chaix

Unité propre de Recherche, Génétique forestière,

73, rue Jean-François Breton B40/16,

34398 Montpellier Cedex 5, France the sapwood but its content increased dramatically in the heartwood. 2-(Hydroxymethyl)anthraquinone and P1, an unidentified compound, were only detected in the heartwood and at high concentrations ( $>3 \mathrm{mg}$ equivalent 5methoxyflavone $\mathrm{g}^{-1}$ dry weight. Lower concentrations of 1,4-naphthoquinone, anthraquinone-2-carboxylic acid, and lapachol were also only detected in the heartwood. H1 and tectoquinone present in the sapwood could be considered as phenolic precursors of the synthesis of heartwood toxic phenolics in the heartwood.

- Conclusion Correlations between natural durability and chemical composition of heartwood (quinone derivatives, P1, and non-structural carbohydrates) suggest that P1, 2-(hydroxymethyl)anthraquinone and tectoquinone could be natural durability traits. Heartwood extractives,
F. B. Niamké · A. A. Adima

Laboratoire de Procédés Industriels de Synthèse de

l'Environnement et de l'Energie Nouvelle (LAPISEN),

Unité Chimie des Eaux et des Substances Naturelles,

Institut National Polytechnique Houphouët Boigny,

B.P. 1313 Yamoussoukro, Côte d'Ivoire

F. B. Niamké · S. Kati-Coulibaly

Laboratoire de Nutrition et Pharmacologie de 1'UFR,

Biosciences 22,

B.P. 582 Abidjan 22, Côte d'Ivoire

F. B. Niamké · Y. Baissac $\cdot$ C. Jay-Allemand $(\bowtie)$

Université Montpellier 2 \& IRD

UMR 47 DIADE, Equipe SMART, LBPV,

Place Eugène Bataillon,

34095 Montpellier Cedex 05, France

e-mail: Christian.jay-allemand@univ-montp2.fr 
mainly quinone derivatives, were formed from nonstructural carbohydrates which were weakly correlated to natural durability.

Keywords Tectona grandis . Teak heartwood . Phenolic compound · Non-structural carbohydrate . Natural durability

\section{Introduction}

Tectona grandis L. f. (teak) grows naturally throughout southeastern Asia. It is one of the most valuable tropical hardwood species on the international market. Teak timber is prized for its workability and high natural durability (Pandey and Brown 2000), which make it suitable for different purposes including house construction, shipbuilding, furniture making, poles, veneer, and carvings.

Traditionally, teak plantations were managed on rotations of 60 to 80 years. With the increasing population and pressure on land tenure and the involvement of private industry, teak plantations are increasingly managed on shortened rotations. This practice induces a high variability in wood properties such as color and natural durability (Bhat and Florence 2003; Kokutse et al. 2006). Natural durability is an important feature of wood which mainly determines its use, and variability has been observed both within and between trees. In teak, natural durability is ascribed to the presence of toxic extractives mainly quinone (Da Costa et al. 1958; Haluk et al. 2001). Previous studies suggested that extractives are formed from reserves materials (Datta and Kumar 1987; Nobuchi et al. 1996). Difference in natural durability may be related to the concentrations of non-structural carbohydrates (NSC) and toxic extractives which are synthesized during heartwood formation (Magel et al. 1997).

Heartwood formation is the specific process that transforms sapwood into heartwood. In temperate species, this process is well documented (Magel et al. 1994, 2001), whereas it is poorly understood in tropical species. In teak, heartwood formation starts when trees are 6 to 8 years old, continues until 30-35 years, and then slows down (Kokutse et al. 2004). Based on histochemical methods, it has been shown that metabolic activities throughout the sapwood and within the transition zone lead to the biosynthesis of heartwood extractives from reserve materials (Datta and Kumar 1987; Nobuchi et al. 1996). Until now, classic approaches based on the radial distribution of extractives in the sapwood to heartwood were developed for teak to determine chemical traits related to its natural durability against insects (Lukmandaru and Takahashi 2009; Bhat et al. 2005). This led to phenolic structures as anthraquinones and naphthoquinones being identified as important for natural durability. However, no reliable information was provided to better understand the origin of natural durability through the transformation of non-structural carbohydrates into phenolic compounds accumulated in the heartwood after wood drying. To our knowledge, quantitative data concerning the biochemical aspects of heartwood formation in teak are not available. Therefore, this paper focuses on the radial distribution of non-structural carbohydrates and phenolic compounds with reference to wood samples collected from teak trees ranking by contrasting levels of heartwood decay resistance (class 1 to class 3 ). In order to identify the phenolic compounds responsible for natural durability assessed by fungal tests, and to know if non-structural carbohydrates could modify the wood protection, correlations between decay resistance and biochemical attributes (phenolic compounds and non-structural carbohydrates) were investigated. While residual nonstructural carbohydrates do not alter the heartwood decay resistance, two newly identified phenolic compounds are related to heartwood formation and wood protection against fungi.

\section{Materials and methods}

\subsection{Plant material}

Six trees of teak (Table 1, step 1) were harvested in Malaysia. One log of $40 \mathrm{~cm}$ length was cut at breast height for each tree. A transversal wood slice was removed from the wood $\log$ (Fig. 1). From well-characterized slice, four wood blocks $(25 \times 25 \times 10 \mathrm{~mm}$, radial, transversal, and longitudinal directions, respectively) were taken successively from the sapwood to the pith: sapwood (SW), outer heartwood (OHW), middle heartwood (MHW), and inner heartwood (IHW; Fig. 1, step 1; Table 1) at a relative distance along the length of the radius of $0.9,0.6,0.4$, and 0.15 , respectively. These wood samples were used for the chemical analyses. For the decay test, a long slice in the outer heartwood was used to obtain 12 wood samples $(25 \times$ $15 \times 50 \mathrm{~mm}$, radial, transversal, and longitudinal directions, respectively): six for the decay test and six for the determination of moisture content (Fig. 1, step 2). All the wood samples were conditioned in a climatic room (humidity, $65 \pm 5 \%$, temperature $20 \pm 1^{\circ} \mathrm{C}$ ) until their use.

\subsection{Wood decay tests}

Natural durability bioassays against Antrodia sp. and the durability rating were assessed according to European standards EN 350-1 (AFNOR 1994) and EN 113 (AFNOR 1996). For each tree, six wood samples (a total of 36 
samples) were weighed (M1), sterilized (gamma ray), and then exposed to the fungi under controlled conditions $\left(21^{\circ} \mathrm{C}\right.$ and $70 \% \mathrm{RH})$. Ten additional samples $(25 \times 15 \times 50 \mathrm{~mm}$ in the radial, the tangential, and the longitudinal directions; Fig. 1) of Pinus sylvestris (control) were used to test fungal virulence. After exposure for 16 weeks, mycelium was removed from the wood blocks, and the samples were dried at $103^{\circ} \mathrm{C}$ to constant mass to determine the oven dry mass (M0f). The other six wood samples from the strip were not exposed to the fungi and dried to $103^{\circ} \mathrm{C}$ until constant mass to obtain the mean moisture content (MC). This was then used to calculate the initial dry mass (M0i) of each wood block tests. The percentage of mass loss (ML) based on dry weight (M0i) was calculated according to the equations below.

$\mathrm{M} 0 \mathrm{i}=\mathrm{M} 1 \times 100 /(100+\mathrm{MC})$

$\mathrm{ML}=100 \times(\mathrm{M} 0 \mathrm{i}-\mathrm{M} 0 \mathrm{f}) / \mathrm{M} 0 \mathrm{i}$

where M0i is the initial dry mass of the wood block tests, $\mathrm{M} 1$ is the initial conditioned mass, MC is the moisture content, and M0f is the dry mass of the sample after exposure to the fungus. The mean mass loss was used to determine the natural durability classes for each tree.

\subsection{Chemical analyses}

The authentic compounds: 2-(hydroxymethyl)anthraquinone and 1,4-naphthoquinone were purchased from Fluka (Switzerland); 2-methylanthraquinone (tectoquinone), 2-hydroxy 3 [3 methyl-2-butenyl] 1,4-naphthoquinone (lapachol), anthraquinone-2-carboxylic acid, and gluconolactone were obtained from Aldrich (Steinheim, Germany); and 5methoxyflavone was obtained from Alfa Aesar (Karlsruhe, Germany). All the solvents (acetone, ethanol, and methanol) used in this study were HPLC grade.
2.4 Extraction and analysis of phenolic compounds

The wood samples used for chemical analyses (Fig. 1, step 1) were ground to particles of $0.5 \mathrm{~mm}$ in size in a Retsch ZM 200 mill (Oise, France). Soluble phenolics were two times extracted by sonication (Selecta apparatus, Lissieu, France; $45 \mathrm{~min}$ at $4^{\circ} \mathrm{C}$ and $\mathrm{pH}=2$ ) from the dried wood powder $(50 \mathrm{mg})$ in $1.8 \mathrm{~mL}$ acetone/water $(80: 20, v / v)$ containing 5-methoxyflavone $\left(2 \times 10^{-4} \mathrm{M}\right)$ as internal standard and gluconolactone $\left(2 \times 10^{-4} \mathrm{M}\right)$ to avoid degradation by $\beta$-glucosidase enzyme. The samples were centrifuged (Mini Spin Eppendorf centrifuge, Le Pecq, France; $15 \mathrm{~min}$ at $13,400 \mathrm{rpm}$ ). The supernatants were pooled and dried under nitrogen flow overnight (sample concentrator TECHNE Dri-Block DB-3, Nemours, France). The residue was dissolved in $850 \mu \mathrm{L}$ pure methanol, and $20 \mu \mathrm{L}$ of the final extract was analyzed by high performance liquid chromatography (HPLC).

HPLC analyses were performed with a Kontron apparatus (Entraigues, France) using an Uptisphere column ODB $5 \mu \mathrm{m} \mathrm{RP}-18,250 \times 4.6 \mathrm{~mm}$. HPLC conditions were as follows: mobile phase: solvent $\mathrm{A}=$ water/acetic acid (99:1, $v / v)$, solvent $\mathrm{B}=$ methanol/acetonitrile $(1: 1, v / v)$; elution gradient $=0-21 \mathrm{~min} 30 \% \mathrm{~B}, 21-25 \mathrm{~min} 30-55 \% \mathrm{~B}, 26-$ $28 \mathrm{~min}, 55-70 \% \mathrm{~B}, 29-34 \mathrm{~min} 70-90 \% \mathrm{~B}$, and $35-$ $40 \mathrm{~min} 90-30 \% \mathrm{~B}$; flow rate $1 \mathrm{ml} \mathrm{min}^{-1}$; and detection 254 and $325 \mathrm{~nm}$. Each compound was characterized by its retention time and its UV spectra recorded between 200 and $400 \mathrm{~nm}$. Quinone derivatives like anthraquinones (tectoquinone, 2-(hydroxymethyl)anthraquinone, and anthraquinone-2-carboxylic acid) and naphthoquinones (1,4-naphthoquinone and lapachol) were identified by comparison with authentic compounds analyzed separately and by cochromatography.

The quantification of the main soluble phenolic compounds and the authentic compounds from quinone family were performed at $254 \mathrm{~nm}$. Their contents were expressed as mg equivalent 5-methoxyflavone $\mathrm{g}^{-1}$ dry weight (dw).

Table 1 Trees and samples characteristics

\begin{tabular}{llllllll}
\hline Tree number & Age (years) & Girth at bh (cm) & Height (m) & $\begin{array}{l}\text { Width of } \\
\text { sapwood (cm) }\end{array}$ & $\begin{array}{l}\text { Width of } \\
\text { heartwood (cm) }\end{array}$ & $\begin{array}{l}\text { Number of radial } \\
\text { positions }\end{array}$ & $\begin{array}{l}\text { Number of samples at } \\
\text { each radial position }\end{array}$ \\
\hline 1 & 10 & 43 & 12 & 1 & 4 & 4 & 4 \\
2 & 7 & 63 & 16 & 2 & 5 & 4 & 4 \\
3 & 10 & 67 & 20 & 2 & 7 & 4 & 4 \\
4 & 10 & 60 & 19 & 2 & 6 & 4 & 4 \\
5 & 6 & 59 & 24 & 4 & 4 & 4 & 4 \\
6 & 6 & 59 & 18 & 2 & 4 & 4 \\
\hline
\end{tabular}

bh breast height

${ }^{a}$ The radial position is the location of the sample on the radial profile of the wood. It can be sapwood, outer heartwood, middle heartwood, or inner heartwood (see Section 2 for more details) 
Fig. 1 Diagram of the wood samples used for chemical analyses (Step 1) and natural durability measures (Step 2).

Transverse slices were sawn from stem discs from the different trees. White or black rectangles in the diagram indicate wood samples. Wood samples were collected from sapwood $(\mathrm{SW})$, outer heartwood $(\mathrm{OHW})$, middle heartwood $(\mathrm{MHW})$, and inner heartwood $(I H W)$. Another wood slice was collected longitudinally in the outer heartwood for natural durability assessment

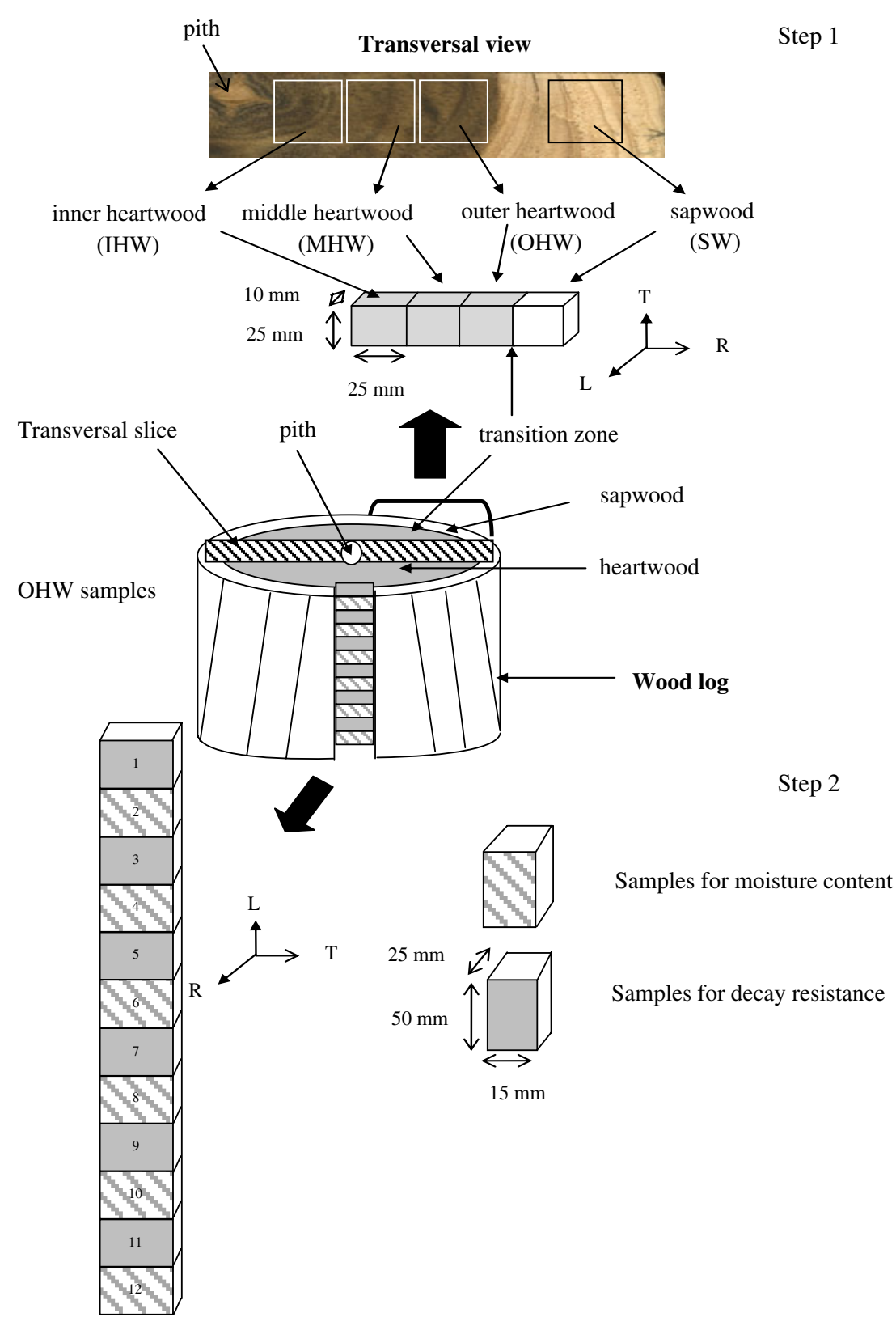

The coefficient of variation of the extraction, separation, and measurement procedure determined from six replicates of the same powder from each radial position never exceeded $8 \%$.

\subsection{Extraction and analysis of non-structural carbohydrates}

Wood powder $(50 \mathrm{mg})$ was extracted three times $(30 \mathrm{~min}$ at $\left.90^{\circ} \mathrm{C}\right)$ with $1 \mathrm{~mL}$ of ethanol/water $(80: 20, v / v)$ and centrifuged. After treatment with $800 \mu \mathrm{L}$ of polyvinylpolypyrrolidone and $400 \mu \mathrm{L}$ of activated charcoal, the filtered aliquots were dried under nitrogen flow concentrator (TECHNE Dri-Block DB-3, Nemours, France). The dry extract was dissolved in $1 \mathrm{~mL}$ of pure water and used for measurements. Starch was hydrolyzed from the remaining residue with $1 \mathrm{~mL}$ of $0.02 \mathrm{M}$ sodium hydroxide $\left(1 \mathrm{~h}, 90^{\circ} \mathrm{C}\right)$. The treated residue was then hydrolyzed into glucose with $\alpha$-amyloglucosidase (E.C. 3.2.1.3; 7U; Fluka). After incubation for $1 \mathrm{~h}$ at $50^{\circ} \mathrm{C}, 50 \mu \mathrm{L}$ aliquots were assayed for glucose as described by Silpi et al. (2007).

The major NSC (starch, glucose, fructose, and sucrose) were measured enzymatically by UV methods as described by Silpi et al. (2007) with a spectrophotometer (Bio-Tek Instruments, Colmar, France). NSC content is expressed as $\mu \mathrm{mol} \mathrm{g}^{-1} \mathrm{dw}$. Starch content is expressed as $\mu \mathrm{mol}$ bond glucose $\mathrm{g}^{-1} \mathrm{dw}$. The coefficient of variation of the extraction and measurement procedure determined from three independent replicates of the same powder never exceeded $8 \%$. 


\subsection{Statistical analysis}

XLSTAT software (Paris, France) was used for the statistical analyses. The Mann-Whitney non-parametric test was used for data which were not normally distributed to determine significant differences of non-structural carbohydrate and phenolic compound contents. Differences were determined within the radial position between sapwood and outer heartwood, between outer heartwood and middle heartwood, and between middle heartwood and inner heartwood. The non-parametric Kruskal-Wallis test was used to test the main effects of radial position and tree. The relationships between mass loss and phenolic compounds and between mass loss and non-structural carbohydrates were studied using the nonparametric Spearman correlation. Values were considered to be statistically significant at $p<0.05$.

\section{Results}

\subsection{Radial distribution of NSC}

Starch content ( $72 \mu \mathrm{mol}$ bond glucose $\mathrm{g}^{-1} \mathrm{dw}$; Fig. 2) was six times higher than monomeric and dimeric non-structural carbohydrates in the sapwood. The heartwood is not free of non-structural carbohydrate; low concentrations of starch were found in outer heartwood and the content of starch decreased with distance into the heartwood. Glucose $\left(12 \mu \mathrm{mol} \mathrm{g}^{-1} \mathrm{dw}\right)$ and fructose $\left(13 \mu \mathrm{mol} \mathrm{g}^{-1} \mathrm{dw}\right)$ were the main soluble NSC in teak sapwood (Fig. 2) relative to sucrose $\left(4 \mu \mathrm{mol} \mathrm{g}{ }^{-1} \mathrm{dw}\right)$. The NSC content in teak wood was compared between six individual trees. In the sapwood, the individual pattern of soluble NSC for each tree (starch $>$ glucose, fructose $>$ sucrose) was similar to that of the general pattern. From a quantitative point of view, polymeric NSC (sucrose and starch) contents in wood varied between trees ( $H=12.04, p<$ 0.001 ; Table 2) whereas no significant difference was found in the content of glucose and fructose.

\subsection{Radial distribution of phenolic compounds}

Quinones were detected and characterized by cochromatography with their standards and their UV spectra. Unidentified compounds were characterized by their retention time and UV spectra. Quantitative results of individual quinones and phenolic compounds were described in Fig. 2. In sapwood, two main phenolic compounds were detected: H1 a hydroxycinnamic acid derivative (retention time $9.74 \mathrm{~min}$, maximum absorption $(\lambda \max )=329 \mathrm{~nm})$ and tectoquinone (retention time $34 \mathrm{~min}$ and $\lambda \max =255 \mathrm{~nm}$ ). Relatively, low concentrations of phenolic compounds were found in sapwood compared to heartwood (Fig. 3). Tectoquinone was detected in both

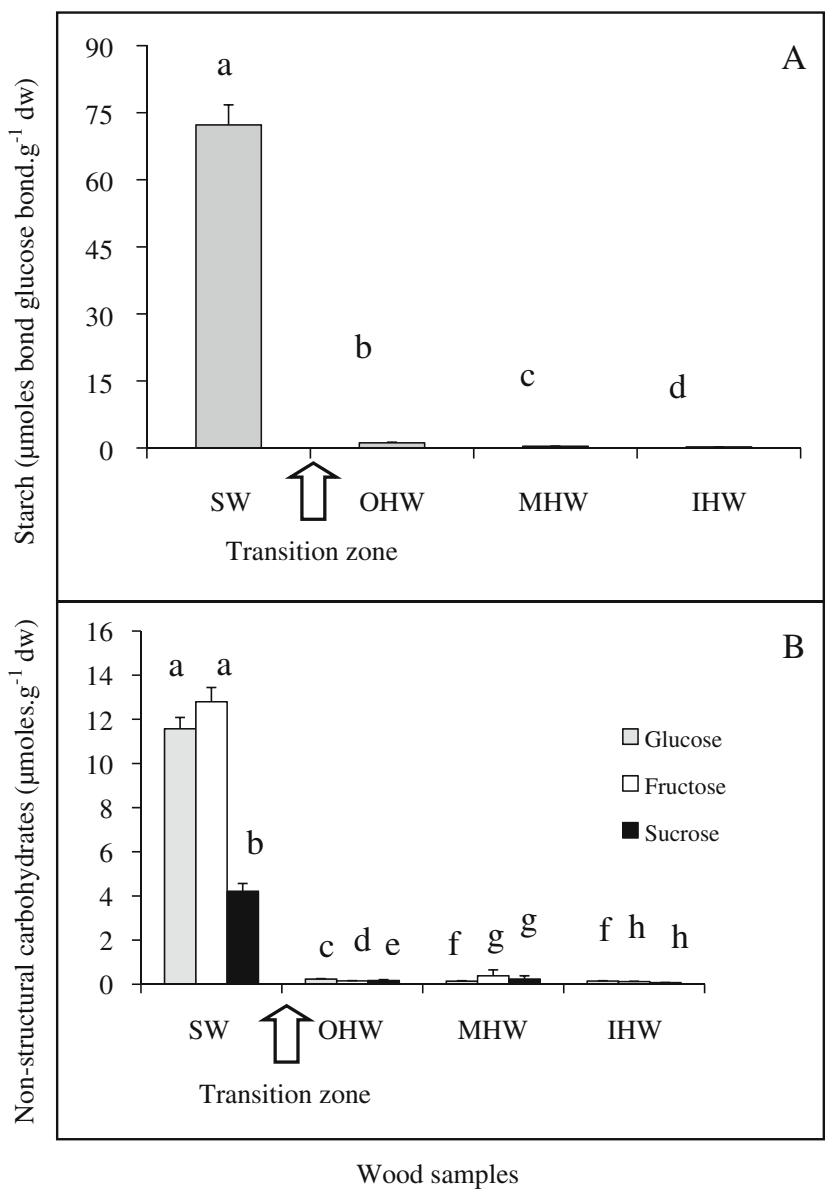

Fig. 2 Soluble non-structural carbohydrate contents in teak (Tectona grandis L. f.): glucose, fructose, and sucrose in sapwood $(S W)$ and heartwood $(H W)$. Heartwood is divided into outer heartwood $(\mathrm{OHW})$, middle heartwood $(M H W)$ and inner heartwood $(I H W)$. Values are the mean of 6 independent samples for the sapwood and for the outer, the middle, and the inner heartwood. Standard deviations are displayed as bars. $a-h$ indicate statistically significant values using the MannWhitney test when $p<0.05$

sapwood and heartwood. Its content increased abruptly from the sapwood to the outer heartwood where it peaked (7.9 mg equivalent 5-methoxyflavone $\mathrm{g}^{-1} \mathrm{dw}$ ) and decreased from the outer to the inner heartwood $(6.0 \mathrm{mg}$ equivalent 5 -methoxyflavone $\mathrm{g}^{-1} \mathrm{dw}$ ). It represented $0.3 \%$ to $0.5 \%$ $w / w \mathrm{dw}$ in the heartwood. Along with tectoquinone, two other major phenolic compounds were detected in heartwood alone: an unknown compound named P1 (retention time $9.74 \mathrm{~min}, \lambda \max =249 \mathrm{~nm}$ ) and 2-(hydroxymethyl)anthraquinone (retention time $27.67 \mathrm{~min}, \lambda \max =254 \mathrm{~nm}$ ). These compounds were not detected in the sapwood, but were accumulated in heartwood. 2-(Hydroxymethyl)anthraquinone $\left(3.0 \mathrm{mg}\right.$ equivalent 5 -methoxyflavone $\mathrm{g}^{-1} \mathrm{dw}$, Fig. 3) and P1 (3.5 mg equivalent 5-methoxyflavone $\mathrm{g}^{-1} \mathrm{dw}$, Fig. 3) contents were higher in the outer heartwood than in the other parts of the tree. 


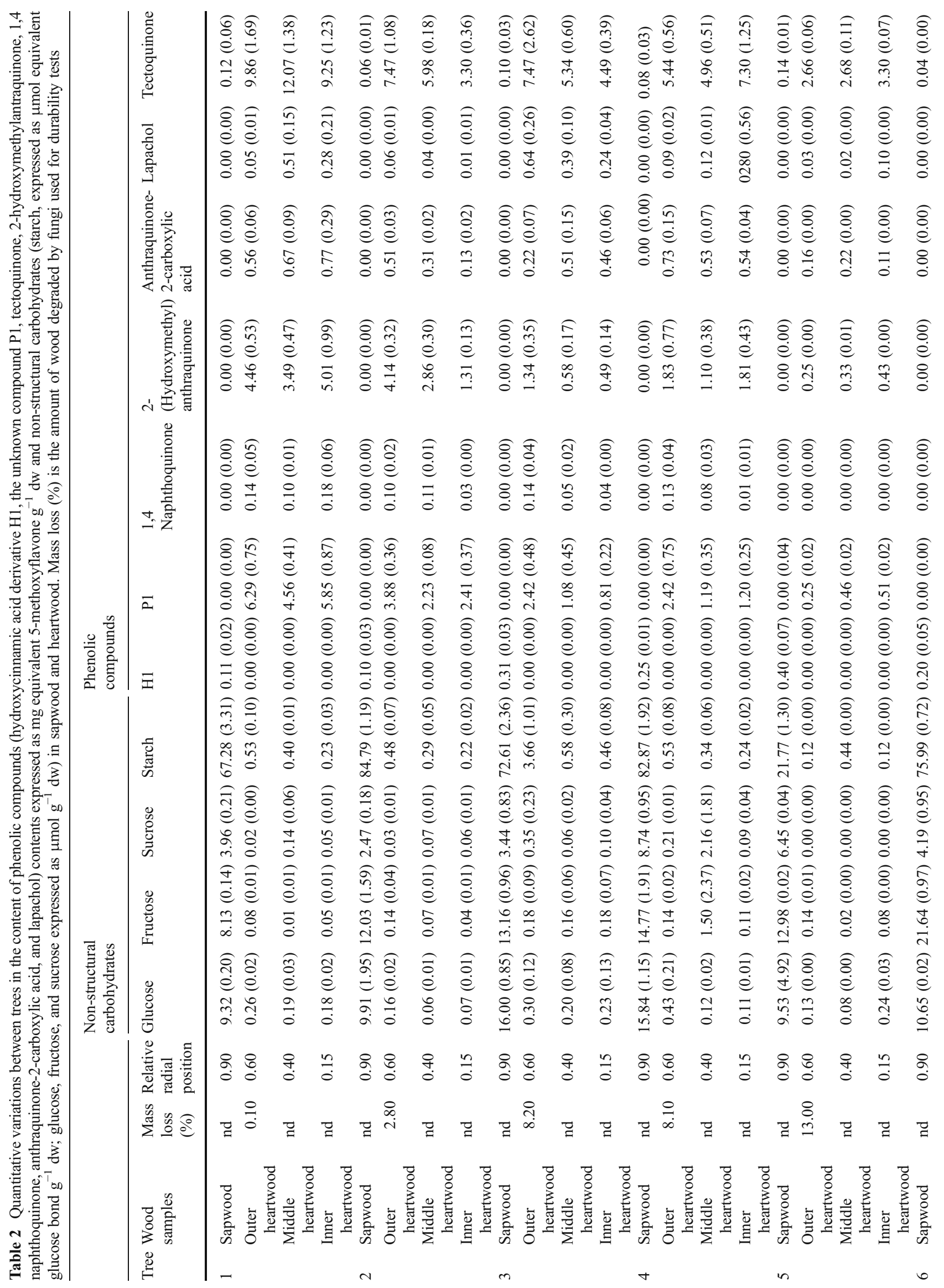




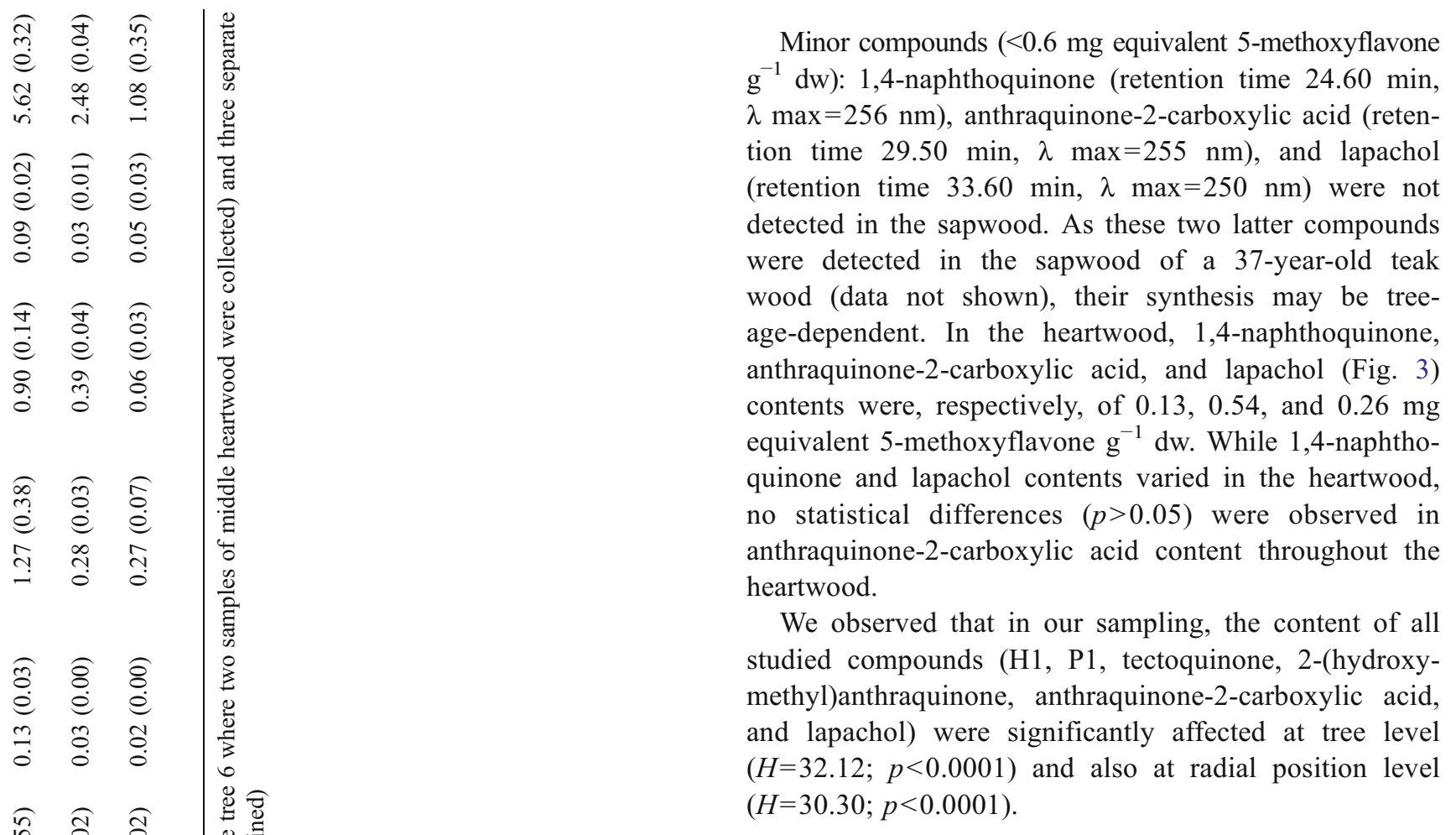

3.3 Decay resistance and its relationship with chemical compounds

The mean mass loss determined with pine wood samples was $28 \%$. This value was higher than the minimum value recommended by the European standard EN 350-1 (AFNOR 1994) and validated the decay test. The mass losses caused by Antrodia sp. in the teak samples ranged from $0.1 \%$ (tree 1 ; class 1 highly resistant) to $14.5 \%$ (tree 6 ; class 3 moderately resistant) indicating a high degree of variability among the six trees (Table 2). In order to determine the chemical compounds related to decay resistance, their correlations with mass loss were determined using the Spearman correlation test. In heartwood, non-structural carbohydrates (glucose and starch) were negatively correlated to mass loss $(r=-0.43)$ : lower mass losses are associated with higher amounts of starch or glucose. High negative Spearman correlations were found between phenolic compounds and mass loss $(r=-0.79$ to -0.90 ) indicating that mass loss decreased with an increase in phenolic content (Table 3). The Spearman correlation was as follows, in decreasing order: P1 $(r=$ $-0.9)>2$-(hydroxymethyl)anthraquinone $(r=-0.82)>$ tectoquinone $(r=-0,71)$. Thus, these compounds could explain the high inter-tree decay resistance (Table 2). Conversely, 1,4-naphthoquinone, anthraquinone-2carboxylic acid, and lapachol contents were not correlated with decay resistance (Table 3) even though lapachol has been reported to exhibit fungicidal and termicidal effect in vitro (Haluk et al. 2001) 


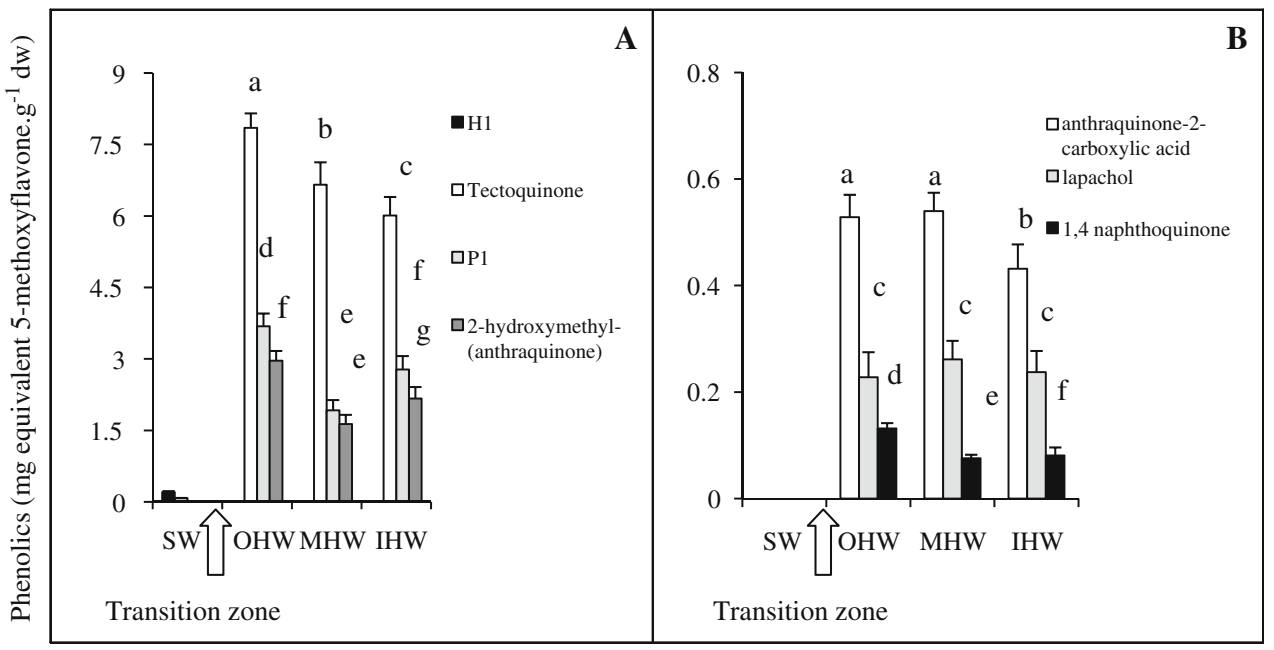

Wood samples

Fig. 3 Phenolic compounds in teak (Tectona grandis L. f.): Unidentified compounds are $\mathrm{H} 1$ and $\mathrm{P} 1$. Identified compounds are tectoquinone, 2(hydroxymethyl)anthraquinone, anthraquinone-2-carboxylic acid, lapachol, 1,4-naphthoquinone. They are detected at $254 \mathrm{~nm}$ in wood samples from the sapwood $(S W)$ and heartwood $(H W)$. Heartwood is divided into outer heartwood $(O H W)$, middle heartwood $(M H W)$, and inner heartwood $(I H W)$. Values are the mean of six separate samples for the sapwood and for the outer, the middle, and the inner heartwood. Standard deviations are displayed as bars. $a-g$ indicate statistically significant values using the Mann-Whitney test when $p<0.05$

\section{Discussion}

In teak, the main non-structural carbohydrates are starch and soluble non-structural carbohydrates (glucose, fructose, and sucrose). Starch was found to be the main available reserve carbohydrate in sapwood as previously shown in teak from Thailand by Nobuchi et al. (2005) who used histochemical observations. Starch content was six times higher than monomeric and dimeric NSC in sapwood. The main forms of soluble NSC were glucose, fructose, and sucrose, as usually found in woody species such as Fagus sylvatica and Cornus sericea (Ashworth et al. 1993). Stachyose, raffinose, and two unidentified NSC were also detected by thin layer chromatography in the sapwood of teak from the same samples (data not shown). NSC contents decreased dramatically from sapwood to heartwood. In the heartwood, trace amounts of NSC were found.

The drastic decrease in NSC contents from the sapwood to the heartwood suggests that NSC are metabolized at the sapwood-heartwood boundary. In this zone, starch and sucrose could be hydrolyzed by their metabolizing enzymes such as amyloglucosidase, sucrose synthase (Susy), and invertases for metabolic activities (Hauch and Magel 1998). However, we cannot exclude the possibility that the low NSC contents found in teak may be caused by NSC degradation due to collection and storing of the wood samples. The radial distribution observed for NSC in the stem wood indicates that NSC could play a key role in the synthesis of heartwood extractives and their accumulation during heartwood formation in teak (Datta and Kumar
1987; Nobuchi et al. 2005). NSC are likely to be the major source of carbon skeletons for the synthesis of heartwood extractives, as previously postulated by Hillis and Hasegawa (1963), and for metabolic activities (respiration, photosynthesis, cambial activities).

In teak, extractives are mainly phenolic compounds from the quinone group. From previous studies, it has been shown that teak extractives are responsible for the decay resistance property (Rudman and Gay 1963; Lukmandaru and Takahashi 2009). This conclusion was based on the correlations between quinone derivatives and natural durability against termite attack. In order to study the chemical traits of decay resistance in teak wood, we used HPLC to analyze quinone derivatives (naphthoquinones and anthraquinones) and unidentified phenolic compounds.

In the sapwood, the main phenolic compounds were tectoquinone and the hydroxycinnamic acid derivative H1. Our results differ from those of Lukmandaru and Takahashi (2009) who found more than two main compounds (tectoquinone, lapachol, desoxylapachol, and its isomer, tectol, squalene, and palmitic acid and two unknown compounds) in Java teak sapwood using ethanol-benzene extract analyzed by gas chromatography.

In heartwood, tectoquinone was the main phenolic compound and its content in the outer heartwood was higher than $0.20 \%$ reported for the same part of 8-year-old teak from Java (Lukmandaru and Takahashi, 2009). However, it is in good accordance with that reported for 35 -years old teak from Nilambour, Kerala (Thulasidas and Bhat 2007). Tectoquinone content, however, is approxi- 


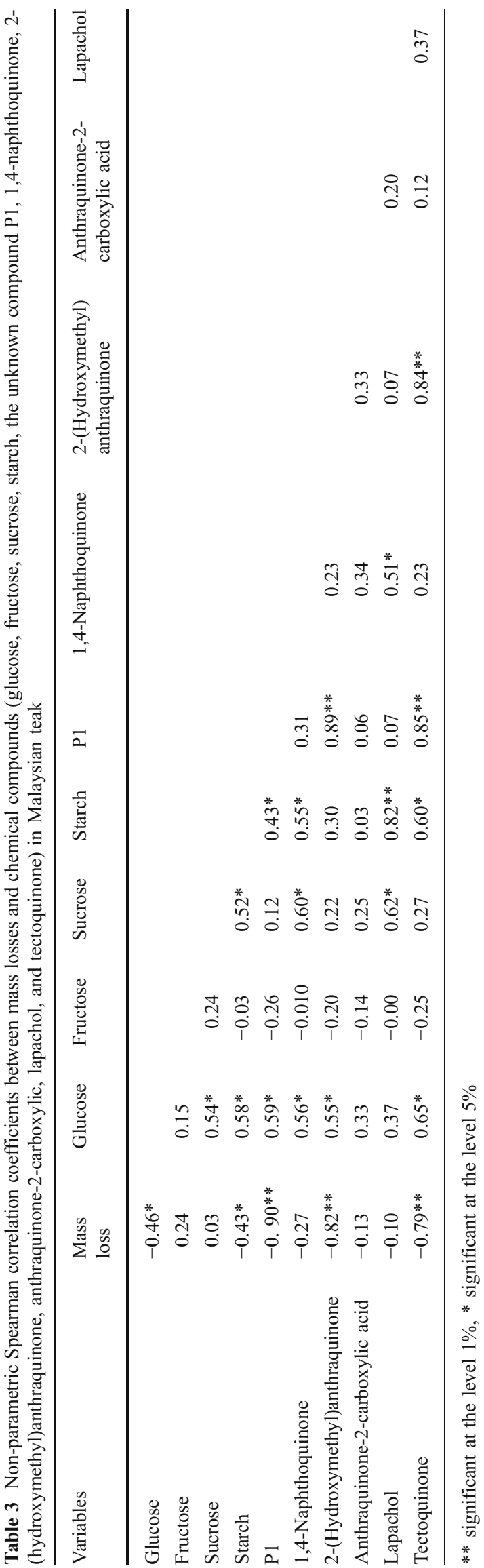

mately two times lower than that found in 30-year-old teak from Panama (Windeisen et al. 2003). Along with tectoquinone, P1 and 2-(hydroxymethyl)anthraquinone were the main phenolic compounds found in teak heartwood. Their content varied in the heartwood with the lower P1 and 2(hydroxymethyl)anthraquinone content in the inner heartwood probably being due to juvenile wood rather than aging. This is supported by Lukmandaru and Takahashi (2009) who observed that no aging or detoxification of extractives occurs in teak before 51 years. Other minor compounds (1,4-naphthoquinone, anthraquinone-2carboxylic acid, and lapachol) were also found in the heartwood. The amount of 1,4-naphthoquinone $(0.02 \% \mathrm{w} /$ $w \mathrm{dw})$ determined in this study was less than the value of circa $1.3 \%$ reported for 35-year-old Indian teak by Thulasidas and Bhat (2007), who used semi-quantitative thin layer chromatography. Differences were also observed for lapachol in measurements on Javanese teak, where this compound was shown to be one of the major heartwood compounds (Lukumandaru and Takahashi, 2009). The radial pattern of phenolic compounds shows that compounds such as P1, 1,4-naphthoquinone, anthraquinone-2-carboxylic acid, and lapachol were detected only in the heartwood. As lapachol, anthraquinone-2-carboxylic acid, and 2(hydroxymethyl)anthraquinone were also detected in the sapwood of 37-year-old teak wood (data not shown), P1 (unknown structure) and 1,4-naphthoquinone biosynthesis could be related to heartwood formation process and could play a key role in the decay resistance of teak. The differences in content of phenolic compounds in teak wood from different localities (Malaysia, Java, or Kerala) could possibly be the result of methods used and environment (climate, soil quality, etc.) or genetic factors as previously suggested by Thulasidas and Bhat (2007).

As generally observed, the majority of teak heartwood extractives were synthesized in the aging sapwood (at the transition zone) and the highest extractive contents were observed in the outer heartwood. Indeed, a low concentration of tectoquinone was found in the sapwood, whilst it was the most abundant phenolic compound in the heartwood. With the presence of tectoquinone and $\mathrm{H} 1$ in sapwood and the absence of $\mathrm{H} 1$ in heartwood, we cannot exclude that they could be the phenolic precursors for the synthesis of heartwood phenolics. This observation was also made for hydrojuglone glucoside, the precursor of juglone, and its polymers in the heartwood of Juglans nigra (Burtin et al. 1998) and to a lesser extent, for dihydrorobinetin, the precursor of robinetin synthesis in Robinia pseudoacacia (Magel et al. 1994). Furthermore, other phenolics such as the unknown compound P1 and 1,4naphthoquinone were found especially in the heartwood of teak. This is also the case for robinetin and the hydroxycinnamic acid derivative in $R$. pseudoacacia. Sandermann 
and Simatupang (1968) suggested that desoxylapachol (which was not detected in our samples) is a precursor for the biosynthesis of naphthoquinones and anthraquinones found in teak wood. Furthermore, it exhibits high fungicidal and anti-termite activities. As this compound has been found in both sapwood and heartwood (Lukmandaru and Takahashi 2009), we do not believe that it corresponds to either $\mathrm{H} 1$ or P1.

Many studies of decay resistance variability have shown that in the radial profile, the outer heartwood is more resistant compared to other parts of the wood (Bhat and Florence 2003; Kokutse et al. 2006). In addition, native compounds responsible for the decay resistance were present in the outer heartwood which was not subjected to aging like the inner heartwood. Since the trees in our sample were relatively young (5.5-10 years old), we chose to study decay resistance in the outer heartwood. The outer heartwood decay resistance in these younger trees corresponded to that of inner heartwood in mature trees as observed by Bhat and Florence (2003). In our samples, a high variability of decay resistance was found. The results are in good agreement with those obtained by Bhat and Florence (2003) with Indian teak. These authors showed that the youngest trees (5 years) were less resistant (class 3 , moderately resistant) than oldest ones (13 years) which were highly resistant (class 1) or resistant (class 2) to various fungi. The high variability of decay resistance in teak could be linked to the content of both non-structural carbohydrates and phenolic compounds. In heartwood, lower mass losses were associated with higher amounts of starch or glucose. These results are in agreement with those obtained by Windeisen et al. (2003) who showed that the sapwood of teak from Panama is not resistant despite the presence of toxic compounds, due to the low content of these compounds and the high amount of sugars. However, the degree of correlation $(r=-0.43)$ remained low and could explain the fact that low content of starch and glucose in the heartwood did not affect decay resistance in teak. Additionally, the status of non-structural carbohydrates in heartwood is not the only parameter influencing decay resistance in the wood. The content of toxic extractives affected decay resistance (Haluk et al. 2001) as observed in the present study. P1, 2-(hydroxymethyl)anthraquinone, and tectoquinone were found to be highly correlated with decay resistance. These results indicate that they may be the major chemical compounds responsible for the natural durability against Antrodia sp. Since a high correlation was observed with $\mathrm{P} 1$, its chemical characterization and biological activity against fungi and/or termites should provide reliable information concerning the origin of natural durability. Moreover, our results confirm less precise methods such as global fraction bioactivity, used in the assessment of the tectoquinone-containing fraction.
This compound was also found to be responsible for decay resistance in teak (Haupt et al. 2003; Haluk et al. 2001). These results are supported by previous studies and confirm the role of tectoquinone in decay resistance (Sumthong et al. 2006; Haupt et al. 2003). However, from other studies, it was found that 1,4-naphthoquinone is the most important compound responsible for decay resistance in teak (Thulasidas and Bhat 2007). These contradictions show that searching for decay resistance traits is a complex activity and requires more in-depth investigations. Other components, such as caoutchouc and squalene, may also act as physical or chemical (hydrophobic) barriers contributing to the decay resistance of teak (Yamamoto et al. 1998; Lukmandaru and Takahashi 2009).

Finally, the use of broad-scale sampling would be valuable to confirm the chemical and drying process, involved in the natural durability of teak wood. More data concerning the natural durability of teak is required and could be used to find indirect tools for the assessment of decay resistance in this species.

\section{Conclusion}

To identify natural durability traits in teak, we studied the radial distribution of non-structural carbohydrates and soluble phenolic compounds in trees with varying natural durability levels. In sapwood, we characterized H1, an hydroxycinnamic acid derivative and tectoquinone. In heartwood, three anthraquinones (tectoquinone, 2-(hydroxymethyl)anthraquinone, and anthraquinone-2-carboxylic acid), two naphthoquinones (1,4-naphthoquinone and lapachol), and an unidentified compound named P1 were detected. We found a strong correlation between decay resistance and specific phenolics (P1, 2-(hydroxymethyl)anthraquinone, and tectoquinone) in heartwood. Conversely, no strong correlation could be established with NSC, showing that NSC, along with phenolic extractives of sapwood, are responsible for the synthesis of heartwood phenolic compounds. Nevertheless, heartwood formation in tropical species is still poorly understood, justifying future investigations into the identification of P1 and $\mathrm{H} 1$ that should provide new insights into the chemical mechanisms underlying decay resistance in teak. Furthermore, the use of samples frozen just after tree felling which allows maintaining the integrity of cells may provide relevant information concerning the heartwood formation process in teak. This could provide complementary knowledge concerning other mechanisms (enzymatic, oxidative pentose-phosphate pathway, etc.) involved in heartwood formation. That would make possible comparisons between the strategies that woody species have developed during their evolution to increase their natural durability through heartwood formation. 
Acknowledgments The authors are grateful to the French Embassy in Ivory Coast for providing a Ph.D. thesis grant for Florence Bobelé NIAMKE and to Nathalie Noël-Boizot for her help during nonstructural carbohydrate analyses.

\section{References}

AFNOR (1994) Norme NF EN 350-1 durability of wood based products - natural durability of solid wood - part 1: guide to principles testing and classification of the natural durability of wood.

AFNOR (1996) Norme NF EN 113 wood preservatives-test method for determining the protective effectiveness against wood destroying Basidiomycetes - determination of the toxic values.

Ashworth EN, Stirm VE, Volenec JJ (1993) Seasonal variations in soluble sugars and starch within woody stems of Corms sericea L. Tree Physiol 13:379-388

Bhat KM, Florence MEJ (2003) Natural decay resistance of juvenile teak wood grown in high input plantations. Holzforsch 57:453455

Bhat KM, Thulasidas PK, Florence MEJ, Jayaraman K (2005) Wood durability of home-garden teak against brown-rot and white-rot fungi. Trees 19:654-660

Burtin P, Jay-Allemand C, Charpentier JP, Janin G (1998) Natural wood colouring process in Juglans species (J. nigra, J. regia and hybrid $J$. nigra $23 \times J$. regia) depends on native phenolic compounds accumulated in the transition zone between sapwood and heartwood. Trees 12:258-264

Da Costa EWB, Rudman P, Gay FJ (1958) Investigations on the durability of Tectona grandis. The Emp For Rev 37(3):291298

Datta SK, Kumar A (1987) Histochemical studies of the transition from sapwood to heartwood in Tectona grandis. IAWA Bull 8 (4):363-368

Haluk JP, Bousta-Roussel C, Thévenon M-F (2001) Importance des quinones dans les propriétés antifongiques du teck (Tectona grandis). Cah Sci bois 1-8

Hauch S, Magel E (1998) Extractable activities and protein content of sucrose-phosphate synthase, sucrose synthase and neutral invertase in trunk tissues of Robinia pseudoacacia L. are related to cambial wood production and heartwood formation. Planta 207:266-274

Haupt M, Leithoff H, Meier D, Puls J, Richter HG, Faix O (2003) Heartwood extractives and natural durability of plantation-grown teakwood (Tectona grandis L.) - a case study. Holz Roh- Werkst 61:473-474

Hillis WE, Hasegawa M (1963) The formation of polyphenols in trees. I. Administration of ${ }^{14} \mathrm{C}$ glucose and subsequent distribution of radioactivity. Phytochemistry 2:195-199

Kokutse AD, Baillères H, Stokes A, Kokou K (2004) Proportion and quality of heartwood in Togolese teak (Tectona grandis L.f.). For Ecol Manag 189:37-48
Kokutse AD, Stokes A, Baillères H, Kokou K, Baudasse C (2006) Decay resistance of Togolese teak (Tectona grandis L.f) heartwood and relationship with colour. Trees 20:219-223

Lukmandaru G, Takahashi K (2009) Radial distribution of quinones in plantation teak (Tectona grandis L. f.). Ann For Sci 66:605

Magel E, Jay-Allemand C, Ziegler H (1994) Formation of heartwood substances in the stemwood of Robinia pseudoacacia L. II. Distribution of nonstructural carbohydrates and wood extractives across the trunk. Trees 8:165-171

Magel E, Hillinger C, Höll W, Ziegler H (1997) Biochemistry and physiology of heartwood formation: role of reserve substances. In: Rennenberg H, Eschrich W, Ziegler H (eds) Treescontributions to modern tree physiology. Backhuys Publishers, Leiden, The Netherlands, pp 477-506

Magel E, Abdel-Latif A, Hampp R (2001) Non-structural carbohydrates and catalytic activities of sucrose metabolizing enzymes in trunks of two Juglans species and their role in heartwood formation. Holzforsch 55:135-145

Nobuchi T, Janmahasatien S, Sakai M (1996) Seasonal changes of wood formation and some characteristics of heartwood formation in teak (Tectona grandis L.) plantation. Kasetsart J Nat Sci 30 (2):254-263

Nobuchi T, Okada N, Nishida M, Siripatanadilok S, Veenin T, Tobing TL, Sahri MH (2005) Some characteristics of wood formation in Teak (Tectona grandis) with special reference to water conditions. In Bhat KM, Nair KKN, Bhat KV, Muralidharan EM, Sharma JK (eds) Quality timber products of teak from sustainable forest management. India, pp. 495-499

Pandey D, Brown C (2000) Le teck dans le monde. Unasylva 201 (51):3-13

Rudman P, Gay FJ (1963) The causes of natural durability in timber part VI. Measurement of anti-termite properties of anthraquinones from Tectona grandis L.f. by rapid semi-micro method. Holzforsch 17:21-25

Sandermann W, Simatupang MH (1968) Terpenoid compounds in Teak and their metabolism. Bull. Nat. Inst. Sci. India 37:158-167

Silpi U, Lacointe A, Kasempsap P, Thanysawanyangkura S, Chantuma P, Gohet E, Musigamart N, Clément A, Améglio T, Thaler $P$ (2007) Carbohydrate reserves as a competing sink: evidence from tapping rubber trees. Tree Physiol 27:881-889

Sumthong P, Damvelg RA, Choi YH, Arentshorst M, Ram AFJ, Hondel VDCA, Cees AMJJ, Verpoorte R (2006) Activity of quinones from teak (Tectona grandis) on fungal cell wall stress. Planta Med 72:943-944

Thulasidas PK, Bhat KM (2007) Chemical extractive compounds determining the brown-rot decay resistance of teak wood. Holz Roh- Werkst 65:121-124

Yamamoto Y, Simatupang MH, Hashim R (1998) Caoutchouc in teak wood (Tectona grandis L.f.): formation, location, influence on sunlight irradiation, hydrophobicity and decay resistance. Holz Roh- Werkst 56:201-209

Windeisen E, Klassen A, Wegener G (2003) On the chemical characterization of plantation teakwood from Panama. Holz Roh- Werkst 61:394-397 